\title{
Bill Manhire
}

\section{From Saga Seminar to Writers' Workshop: Creative Writing at Victoria University of Wellington}

\author{
This paper is based on a keynote address delivered on \\ 23 November 2001 at the AAWP Conference, Writing \\ Realities: The State of the Art, University of Canberra, \\ Australia.
}

It's very kind of Jen Webb and her co-organisers to invite me to the AAWP's Canberra conference. Apart from the fact that it's extremely nice for me, it's perhaps also a small blow in the long-running war against the Australia-New Zealand information gap. Of course I'm stating the obvious in this forum - but sometimes the Tasman can seem like the widest stretch of water on the planet. It's entirely worrying that literary communities like ours go on being so ignorant of one another. The Australian books and authors New Zealanders know about are those which London and New York publishing houses have decided are interesting - and I'm sure that this is equally true the other way about. Our information still comes courtesy of the old centres; there are no cross-city buses; and in terms of our mutual relationship we remain thoroughly colonial.

I think that Jack Hodgins spoke at the last AAWP conference, and I want to notice and applaud how, in his recent writing guide, A Passion for Narrative, he has deliberately used a range of Australian, Canadian and New Zealand examples. He might have gone the usual US/UK way, but as his introductory comments there make clear, there is a case for actively assisting our writers across the invisible borders which the British and American publishing cartels still maintain.

Anyway, this is just a roundabout way of saying that, while I'm personally delighted to be here, I also appreciate the larger gesture that the invitation represents.

Back in 1981 I remember looking at an issue of a literary journal called Helix, which I think was published out of Melbourne. It opened with a longish opinion piece by the editor, Les Harrop, making a case for the teaching of creative writing in the academy. His urgings and arguings came partly out of an anxiety about the then emphases of Departments of English: 'What [critical discussion within creative writing courses] should not do,' he wrote, 'is denude or overlay the art it purports to examine.'

This is twenty years ago, of course, back in the good - or bad - old days before theory and cultural studies had transformed Departments of English, which in turn means that the academics whom Les Harrop saw as somehow 'difficult' were the entirely traditional scholars. 'How do we persuade,' he said, 'the gent who lectures on Old Norse - who has been able to survive largely because the department has set its face against the creative and the contemporary - that it is to everyone's advantage if the balance of the department be tilted away from his subject, and that his best students be siphoned off into the creative writing option?'

I enjoyed this, and subsequently had the satisfaction of reading in a later number of Helix (there was 'An Exchange on Creative Writing', whose contributors included Ian 
Reid, Brian Dibble and Kerryn Goldsworthy and the Canadians George Bowering and George McWhirter) my own triumphantly sniffy letter pointing out that I was in fact someone who did both these things. That's to say, as part of my usual workload at Victoria University of Wellington I was teaching a second-year course in creative writing and a fourth-year course in Old Norse language and literature.

So - in terms of the current growth in tertiary-level creative writing programmes - I suppose I am one of the pre-professionals: a happy amateur who has grown into a set of activities, someone who has made things up as he went along. I think of myself as a poet, but in academic terms I began life as a medievalist, and indeed did once know rather a lot about the Icelandic sagas. And then by a process of slow drift I reached the point where - though I am officially Professor of English and Creative Writing - I am no longer a member of the School of English. In fact, I am officially Director of the International Institute of Modern Letters, which manages Victoria's creative writing programme - a programme which consists of a full-time graduate course, which from next year will enrol 20 students in two MA streams annually, and a range of specialised, competitive-entry undergraduate workshops.

My plan in what I have to say is simply to be informative. I don't think I will have anything surprising to offer you about the philosophy or practice of teaching creative writing - though I intend to go on about these a little. But I can describe the current situation at Victoria, and perhaps end by saying something about the International Institute of Modern Letters with which we are linked.

I'll start by saying a little about the process that took me from the saga seminar to the writing workshop.

Victoria University's course in creative writing is the oldest in New Zealand - at least, the oldest offered for university degree credit. It began in 1975 as a sort of undergraduate thesis paper, giving recognition to students' own writing. There were no formal classes, but final year students of English - i.e. those who had just passed a compulsory course in 18th-century poetry - were able to submit a folio of original writing and receive credit towards their degree.

The course was introduced by the late Professor Don McKenzie - a man you might describe as a charismatic bibliographer. That sounds like a contradiction in terms, but then Don was someone who started life as a New Zealand railway worker's son and ended up as Professor of Bibliography at Oxford, so all the possibilities were somehow there in him. He had been a doctoral student in Cambridge and he wanted to introduce to Victoria something like the possibility which existed - and presumably still exists there, where you could submit a creative dissertation in Part II of the English Tripos as, for example, Sylvia Plath did with a volume of poems in 1957.

Victoria was not at the time an adventurous academic community; and one reason for the relative ease with which creative writing was accepted there (aside from Don McKenzie's persuasive powers) was that we had a very remarkable Department of Music. It taught composition, and was well known for this activity; and it had on its staff a number of leading composers including the late Douglas Lilburn. This is probably also why our creative writing course was known for many years as 'Original Composition'.

Original Composition was at first essentially an assessment opportunity, and it went on like that for a couple of years. There were no classes. But then the students who were enrolled in the course, half-a-dozen of them, began to feel lonely and I was asked by the department chairperson, Stuart Johnston, to arrange some informal meetings where these budding writers could share problems and discuss their work. We met in a shabby prefab room, but it was a good place to be. To start with, everyone actually wanted to be there, which was never something you could safely say of tutorials on Hamlet or The 
Waste Land. And the students were alive, fully present, in ways which were surprising and new. Discussion had both a sense of freedom and a sense of function. The texts being talked about were provisional, still in search of their final form; and they were also unhampered by the received judgements which haunt so many literature tutorials.

In one of these meetings the idea of exercise work came up. Someone (not me) suggested that it might be interesting to see what each writer did with the same set of challenges. We decided to find out and, as we went along, I began to get over-excited and bossy and adventurous. I introduced cranky constraints, strange systems of chance. One early exercise that I'm still inordinately proud of was the instruction to 'write a haiku using only the words you can find on the racing page of the morning paper.'

My memory is that we were all surprised by the quality of the work this exercise produced. We shouldn't have been. New Zealand's best words are there on the racing page: much of the nation's most strenuous creative endeavour has gone into the business of naming horses. (I'm sure this is equally true in Australia - though I feel a strange compulsion, here in the city which displays Phar Lap's heart in its museum, to point out that Phar Lap is beyond all argument a New Zealand horse, and that his extraordinarily resonant name was given him by New Zealanders.)

We were beginning to enter the gaming halls of the imagination. Soon I was asking people to make large cardboard dice, write words on them and throw short poems. Then I was asking students to 'find' poems and bring them to class. I was asking for riddles and spells. I was asking for stories made up of three numbered false starts but which still - somehow - felt complete.

A few years later - this is the early 1980s - I was beginning to have some sense of what was going on. The course had changed in certain ways. It had moved to 200-level, and was available not just to English majors but to anyone who wanted to apply. The prerequisite was now 'any twelve credits', along with something even vaguer: 'a required standard of writing'. This meant that in practice writing samples became our means of deciding admissions. There was space in the workshop for twelve students only, and many, many more were applying. By 1996 there were over 150 applications for the course each year, and we were turning away large numbers of talented writers.

Though the aim of the course was to produce a final folio, exercises had now become central to what we did. I had begun to understand more clearly what function they were serving, and just how they might be useful to new writers meeting in a group.

Creative writing workshops depend on their members behaving in ways which are both sociable and courageous. Students find that they have to read their work aloud; they have to be willing to listen to a dozen other people making comments on it. In turn, they have to be willing to make comments on the work of everyone else in the workshop; they have to be honest without being devastatingly hurtful, and they have to be encouraging without being false or fatuous. In other words, a workshop has to be a functioning community.

I had learnt by trial and error what is obvious to most of us, that exercises can be particularly helpful in the early stages of a workshop. And in some respects, the sillier the exercise, the better. If for example you are an anxious aspiring writer and you are required to write a story that incorporates a number of designated items - say, a child standing in water, a reference to the Oxford Dictionary of Saints, and someone claiming to be a close personal friend of Les Murray - and then in the workshop discussion several people express disappointment with your second-last paragraph, you needn't feel personally hurt or deflated. None of it was your idea.

Exercises can be socially and professionally instructive - in a sense they give us a relatively safe way of practising how to talk and, perhaps harder, how to listen. But even more important, exercises enable us to work each other out. They help us to see 
each other clearly. Every writer has mannerisms - cadences, phrasings, perspectives which are continuous from one piece of writing to the next, so that after a while, and across a range of exercise pieces, we begin to recognise what is distinctive about each of the different voices in the room. My false starts and racehorse names aren't yours. My character who claims to be a close personal friend of Les Murray doesn't remotely resemble your character who seems to be making the same unlikely claim... And so on.

This means that when we reach the point where we begin discussing folio work (the writers' 'real' work) we all know what each person in the room typically sounds like. And this in turn means that any comments we make spring from a real understanding of what is being attempted. We know what a text means to do, what its writer has in mind for it. We can make our observations and interventions on behalf of the emerging poem or story.

The exercises are real work, too, and often the results find their way into course folios and, in many cases, into books and literary magazines. But they are also an active way of giving new writers the experience of what we could maybe call 'creative ignorance'. The need for creative ignorance is something which all kinds of writers seem to agree on. Poems are like dreams, says Adrienne Rich; in them you put what you don't know you know. Or, as David Malouf says, when you write 'you have to fall out of that part of your mind where you know too much, into an area where you don't know anything before the best writing can happen.'

Or in the very succinct phrasing of Grace Paley, if you want to be a writer, 'Stay open and ignorant.'

Exercises can be a way of encouraging new writers to stay open and ignorant, to write what they don't know, to use words as instruments of exploration and discovery rather than as a convenient system for recording already well-considered wisdom. Often we use our imaginations best when we need to solve problems; constraints prompt inventiveness. It is a wonderful moment in the life of a workshop when writers begin to have that experience of being entirely surprised and startled by the words which suddenly appear on the page. Can those ideas and phrasings really have been there in their heads?

If I make rather a lot of the exercise component in our workshops, this is because I believe them to be crucial for teaching workshop protocols, and for encouraging students to jump the tracks imaginatively. I don't myself use exercises to teach particular aspects of craft or technique. These seem to me to be incidental benefits. Mostly I want exercise work to build confidence and community, and to startle writers into a greater sense of their own capacity.

Another thing that characterises what we do at Victoria - and like the exercise work this comes out of the slow evolution of our programme - is the mixing of genres within a single workshop. We started like that in the old Original Composition course, and it's something we've hung onto in the MA programme. A habit has become a pedagogical commitment. This might explain the amount of hybrid work that has come out of our workshops (I'm thinking especially of some of the work of Dinah Hawken and Jenny Bornholdt) and why some of our students begin as novelists and end up as poets, or begin as poets and end up as playwrights.

Like many other writing workshops, we also place a lot of emphasis on reading. Again there was a kind of evolutionary drift over the years: we began with handouts, moved on to prescribed course readers, and now in the MA degree a large component of student time is taken up with a formal requirement called Reading Programme. This involves weekly seminars, which include student presentations as well as writer visits, plus a very substantial reading journal which is submitted at the end of the year. A number of assumptions lie behind this insistence on reading - most obviously the fact 
that writing is continuous with speaking. Just as we learn to speak by listening to the adult voices round about us, so we learn to write by reading.

The Reading Programme, with its various activities, is also crucial to the development of a sense of community. My own belief is that this, far more than money or material success, is the key to whether or not talented people persist as writers. We all produce our work in what Eudora Welty once called An Absolute State of Do Not Disturb - but that is not how most of us spend our lives. Writers live not in tortured isolation but in the world, and in the vast company of other writers. At Victoria, this community includes the MA workshop itself, its writer-visitors, and all those writers - dead or alive - whom our visitors mention, or whom we ourselves read. When Robert Dessaix talked to our MA students last year about his own work as a writer, he also sidetracked onto one of his great loves, nineteenth-century Russian fiction - and at this point Turgenev, Gogol, Chekhov, and Dostoevsky became part of our community. Thus our texts have contexts, and we ourselves have ancestors. If there is something called a literary tradition, then look, we are part of it, too. This sense of community, which persists well beyond a successful workshop, can be an enormously sustaining thing.

Let me say very quickly that about four years ago we made a big shift at Victoria. I had travelled around the USA for a month or so in 1995, getting a sense of how things worked in some of the famous and not-so-famous graduate writing programmes - and in 1997 we introduced our MA (a course limited to ten students) and at the same time added a range of genre-specific undergraduate workshops. We marked the moment of transition with a 330-page book, Mutes \& Earthquakes, which gathered together work by Original Composition graduates, along with essays and exercise ideas from established writers and teachers. (Any careful reader would have noticed that the book's title was nicked from one of the included short stories, but all the same a very large number of contributors individually asked me whether they fell into the category of mute or earthquake. You underrate the paranoia of writers at your peril.)

In 2002 we'll have a larger MA programme. We are introducing a ten-member scriptwriting stream alongside the current ten-member page-writing stream; and we'll have a wider range of undergraduate workshops accepting 12 or - in one case - 15 students. These last will be familiar to people here: poetry and short fiction workshops, children's writing, and creative nonfiction (we've sometimes had science fiction). One course which we trialled very successfully this year, and which may seem a little less usual to you, is called Creative Writing in the Marketplace.

I must take full responsibility for the rather crass commercial title. But the course itself does not entirely deny it. It proceeds from the assumption that there are ways of being creative in the world of books which are just as significant as, say, writing a short story or a sonnet; and so it sets about surveying the ways in which the literary imagination makes its way into the marketplace. The twelve weekly workshops provide a forum for discussing literary magazines, writers' festivals and creative radio, along with publishing, literary journalism and the book trade. There are visits by professionals in the book business and media, such as magazine editors, publishers, booksellers, radio producers and publicity/marketing specialists.

Students are required to choose from three main emphases. They can concentrate on editing a print or web-based literary magazine. (This year's students worked on an issue of Sport, and developed an online magazine, Turbine, which we will continue to publish: www.vuw.ac.nz/turbine.) They can concentrate on designing and staging a literary event: a conference, seminar, readings series, workshop or day/weekend long festival. Or they can concentrate on writing/producing for radio - by adapting published fiction for broadcast, writing their own drama or fiction, or developing and producing documentaries. This last emphasis has depended very much on the generosity and expertise of Radio New Zealand, and has already seen a number of fine documentaries go to air, one of which - on vampires - has been sold on to the ABC. The course is co- 
ordinated by Chris Price, immediate past-editor of Landfall, and co-ordinator of Writers and Readers Week at the New Zealand Festival of the Arts.

I should also say something about the International Institute of Modern Letters, an organisation founded by US writer-turned-businessman Glenn Schaeffer. Through the IIML he has provided Victoria University with enough in the way of endowments and pledges to enable us to keep the size of our workshops small, thus maintaining quality, while at the same time we have been able to extend the range of what we do.

Such support is crucial in New Zealand's tertiary sector at the moment: the combination of massive under-funding by successive governments and the imposition on institutions of a 'more market' philosophy of competition - where government funding simply follows student enrolment - has produced a world in which educators design their curricula almost entirely in terms of what the current cohort of school leavers thinks would be interesting or useful to study. The pressures to develop creative writing and save jobs in departments of English have been great. Quantity pushes hard against quality. Given that the workshop model is deemed financially unprofitable in the brave new dispensation, visions of 300 students sitting in a hall listening to lectures on how to write poems are not as silly as they once seemed.

So Glenn Schaeffer's interventions have been very happy ones at my university. He himself happens to be a graduate of the Iowa Writers' Workshop, but one who went on as a businessman rather than a writer. The Mandalay Resort Group, of which he is president and chief financial officer, owns among much else about a mile of the strip in Las Vegas. If you've stayed in Circus Circus or the Luxor or the Mandalay Bay, then you've stayed in one of Glenn Schaeffer's casinos.

The IIML has several co-centres. Two are at Iowa and UC Irvine, and a third is at the University of Nevada, Las Vegas. At present it is a work-in-progress, still developing its goals and projects. It plans to make the work of third-world writers available in English, which partly explains why the Nobel laureate Wole Soyinka is its Director of Literary Arts, and why the Irvine co-centre will focus its work on literary translation. The IIML is also involved with the International Parliament of Writers' 'Cities of Asylum' programme (the Sierra Leonean writer Syl Cheney Coker is the first writer to seek refuge in - yes - Las Vegas). It will have a publishing program, and in Las Vegas it has been involved in experimental outreach work among the public schools.

More generally, the IIML wishes to support emerging writers. In New Zealand, this means support for Victoria's creative writing programme, specifically through the funding of a headquarters building, the salary for a half-time administrator, and the creation of various scholarships, including a sort of direct entry scholarship for our top MA student into the Iowa Writers' Workshop. Glenn Schaeffer is also funding a biennial 'Prize in Modern Letters' which will see NZ\$60,000 go to an emerging New Zealand writer. (I think this almost certainly makes it the richest literary prize in Australasia.)

Anyway, it is all very extraordinary. It gives those of us involved with creative writing at Victoria a sense of possibility in a mean-spirited time. You can probably see why we enjoy the fact that Glenn Schaeffer likes to describe himself not as a patron or benefactor but as a literary activist.

When I knew I was coming to Canberra, I tried to think just why the Victoria creative writing programme has been so successful, and why it now has such power - for which of course it is as much resented as respected - in New Zealand's literary culture. My feeling is that over the years we have been fortunate in the serendipitous coincidence of a number of things. Some of these I have just rehearsed.

But there have been other helpful contexts and synergies. In particular, our creative writing course grew up with Victoria's writer in residence programme (the first of our annual writing fellows was appointed in 1979) and with Victoria University Press, 
which - if you go by national book awards over the last ten years - is currently New Zealand's leading publisher of fiction and poetry. (VUP's managing editor, Fergus Barrowman, is also the founder editor - in his spare time - of New Zealand's leading literary magazine, Sport.) So there has been a world of writers and books, a visible and active literary community, which our creative writing workshops have been part of. Fergus Barrowman in particular has been involved with the assessment processes for our courses - and so a number of our top students have walked straight into the pages of Sport or into the annual catalogue of Victoria University Press itself. Other New Zealand publishers hang around a lot. We have become a sort of talent-spotting agency.

I want to end with a question, one to which there may or may not be answers. My question is whether or not creative writing courses are beginning to have some impact on the contents - or even the viability - of traditional literary magazines. Have the pathways to publication changed? Once upon a time a poet would spend three or four years publishing poems in little magazines, possibly after several years of writing and unsuccessfully submitting work to those same magazines. Then - once the track record was in place - might come acceptance of a first volume by a publisher. A fiction writer would follow the same journey through the magazines, have a first collection of short stories accepted for publication, and then maybe start work on her first novel. Now writers like Elizabeth Knox or Catherine Chidgey or Kapka Kassabova - all Victoria graduates - tend to write their first novel as part of their degree, and a publisher has it in print six months later. It can be a very fast track to fame these days. What follows that first burst of fame is another question altogether.

Bill Manhire is a prize-winning poet and fiction writer, and has edited a number of bestselling anthologies including $100 \mathrm{New}$ Zealand Poems and The New Zealand Collection (University of Queensland Press). For Oxford University Press he wrote a critical study of the novelist Maurice Gee, and Victoria University Press published his Doubtful Sounds: Essays and Interviews in 2000. In 1998 he was visiting Fulbright Professor in New Zealand Studies at Georgetown University, and in 1997 he was appointed New Zealand's first Te Mata Estate Poet Laureate. During this laureate term he spent '45 semi-heroic minutes' at the South Pole.

\section{TEXT}

Vol 6 No 1 April 2002

http://www.griffith.edu.au/school/art/text/

Editors: Nigel Krauth \& Tess Brady

Text@mailbox.gu.edu.au 